\title{
DERAJAT PH SALIVA PADA MAHASISWA PROGRAM STUDI KEDOKTERAN FAKULTAS KEDOKTERAN UNIVERSITAS MALIKUSSALEH YANG MENGKONSUMSI KOPI TAHUN 2020.
}

\author{
Harvina Sawitri ${ }^{1}$, Nora Maulina ${ }^{2}$ \\ ${ }^{1}$ Bagian IKM Program Studi Kedokteran, Fakultas Kedokteran, Universitas Malikussaleh \\ ${ }^{2}$ Bagian Fisiologi Program Studi Kedokteran, Fakultas Kedokteran, Universitas Malikussaleh \\ Corresponding Author : harvina.sawitri@unimal.ac.id
}

\begin{abstract}
Abstrak
Kopi merupakan salah satu minuman yang tidak asing bagi masyarakat Indonesia dan memiliki aroma yang khas yang tidak dimiliki oleh bahan minuman lainnya. Minum kopi saat ini sudah menjadi bagian penting dari gaya hidup sebagian besar orang, karena kopi dianggap mampu mengurangi depresi akibat dari banyaknya dan padatnya aktivitas masyarakat seharihari, termasuk mahasiswa. Kebiasaan minum kopi dapat menyebabkan perubahan $\mathrm{pH}$ saliva karena kandungan sukrosa pada kopi, yaitu dimana sintesa ekstra sel sukrosa lebih cepat daripada gula lainnya, sehingga lebih cepat diubah menjadi asam oleh mikroorganisme di dalam rongga mulut. Penurunan $\mathrm{pH}$ saliva dapat menyebabkan demineralisasi elemenelemen gigi dengan cepat, sedangkan kenaikan $\mathrm{pH}$ dapat membentuk kolonisasi bakteri yang menyimpan juga meningkatnya pembentukan kalkulus. Saliva dengan $\mathrm{pH}$ kritis yaitu 5,5 dapat mengakibatkan disolushidroksiapatit yang disebut demineralisasi pada gigi. Oleh karena itu penelitian ini dilakukan pada mahasiswa Pendidikan Kedokteran Universitas Malikussaleh untuk mengetahui derajat $\mathrm{pH}$ saliva pada mahasiswa yang mengkonsumsi kopi. Populasi pada penelitian ini adalah seluruh mahasiswa Program Studi pendidikan Dokter Fakultas Kedokteran Universitas Malikussaleh angkatan 2016-2018 dengan jumlah sampel 60 . Penelitian ini adalah penelitian observasional dengan menggunakan disain cross sectional, yaitu studi epidemiologi yang mempelajari prevalensi, distribusi, maupun hubungan penyakit dan paparan dengan mengamati status paparan, penyakit atau outcome lain secara serentak pada individu- individu dari suatu populasi pada suatu saat
\end{abstract}

Kata Kunci: pH-saliva, kopi, kebiasaan-minum-kopi

\section{Degree Of Saliva pH In Medical Students Of Medical Study Program Faculty Of Malikussaleh University Who Consumed Coffee In 2020}

\begin{abstract}
Coffee is a drink that is familiar to the people of Indonesia and has a distinctive aroma that is not owned by other beverage ingredients. Drinking coffee has now become an important part of most people's lifestyles, because coffee is considered to be able to reduce depression due to the many and dense activities of everyday people, including students. The habit of drinking
\end{abstract}


coffee can cause changes in salivary $\mathrm{pH}$ due to the sucrose content in coffee, which is where the extra-cell synthesis of sucrose is faster than other sugars, so it is converted into acid more quickly by microorganisms in the oral cavity. A decrease in salivary $\mathrm{pH}$ can lead to rapid demineralization of dental elements, while an increase in $\mathrm{pH}$ can lead to bacterial colonization which also increases calculus formation. Saliva with a critical $\mathrm{pH}$ of 5.5 can cause dissolving hydroxyapatite which is called demineralization of teeth. Therefore, this study was conducted on students of Malikussaleh University Medical Education to determine the degree of salivary $\mathrm{pH}$ in students who consume coffee. The population in this study were all students of the Medical Education Study Program, Faculty of Medicine, Malikussaleh University class 20162018 with a total sample of 60 . This study was an observational study using a cross sectional design, namely an epidemiological study that studied the prevalence, distribution, and the relationship between disease and exposure to simultaneously observing the exposure status, disease or other outcome in individuals from a population at a time

Keywords: $\mathrm{pH}$-saliva, coffee, coffee-drinking habits

\section{PENDAHULUAN}

Kopi merupakan salah satu minuman yang tidak asing bagi masyarakat Indonesia dan memiliki aroma yang khas yang tidak dimiliki oleh bahan minuman lainnya. Minum kopi saat ini sudah menjadi bagian penting dari gaya hidup sebagian besar orang, karena kopi dianggap mampu mengurangi depresi akibat dari banyaknya dan padatnya aktivitas masyarakat seharihari. Seduhan kopi merupakan minuman yang merakyat di berbagai kalangan. Minum kopi bukan sekedar tuntutan selera tetapi sudah menjadi kebiasaan, khususnya dimasyarakat perkotaan (1). Dengan adanya warung-warung kopi ternama sebagai lokasi yang nyaman untuk menikmati secangkir kopi seraya berkumpul dengan keluarga, teman maupun rekan bisnis merupakan salah satu buktinya. Kopi memiliki keunggulan dan pasarnya masingmasing. Kopi di Indonesia diperdagangkan dalam bentuk biji kopi, kopi sangrai, kopi bubuk, kopi instan, dan bahan makanan lainnya yang mengandung kopi (2). Kebiasaan minum kopi dapat menyebabkan perubahan $\mathrm{pH}$ saliva karena kandungan sukrosa pada kopi, yaitu dimana sintesa ekstra sel sukrosa lebih cepat daripada gula lainnya, sehingga lebih cepat diubah menjadi asam oleh mikroorganisme di dalam rongga mulut (3). Kopi merupakan salah satu minuman yang paling banyak dikonsumsi di dunia. Indonesia termasuk konsumen kopi 
dengan presentase konsumsi 6,38\% dari konsumsi kopi total eksportir kopi di dunia. Kopi memiliki dampak positif seperti meningkatkan kinerja dan produktivitas kerja, kopi dapat membuat tubuh menjadi segar lebih lama sehingga dapat memacu aktivitas, mencegah rasa kantuk, menaikkan daya tangkap panca indra, mempercepat daya pikir dan mengurangi rasa lelah. Sedangkan dampak negatif mengkonsumsi kopi seperti timbulnya plak ada bekas kuning pada gigi yang dikarenakan oleh senyawa kafein sehingga plak tersebut dapat memberikan dampak buruk bagi kesehatan gigi yang mengakibatkan gigi berlubang(4).

Derajat keasaman $(\mathrm{pH})$ saliva merupakan faktor penting yang berperan dalam rongga mulut, agar saliva dapat berfungsi dengan baik maka susunan serta sifat dari saliva harus tetap terjaga dalam keseimbangan yang optimal, khususnya derajat keasaman. Karena $\mathrm{pH}$ sangat terkait dengan beberapa aktivitas pengunyahan yang terjadi di rongga mulut. Penurunan $\mathrm{pH}$ saliva dapat menyebabkan demineralisasi elemen-elemen gigi dengan cepat, sedangkan kenaikan $\mathrm{pH}$ dapat membentuk kolonisasi bakteri yang menyimpan juga meningkatnya pembentukan kalkulus (9). Saliva adalah cairan dalam rongga mulut yang tersusun dari 98\% - 99\% air, sementara sekitar 2\% tersusun dari komponen organik, anorganik, elektrolit, mukus, zat- zat antimikroba, dan berbagai enzim (4). Fungsi saliva antara lain adalah untuk lubrikasi jaringan dalam rongga mulut, perlindungan terhadap dehidrasi dan sebagai buffer system untuk melindungi rongga mulut dalam mencegah kolonisasi bakteri patogen dan menetralkan rongga mulut dari keadaan asam sehingga dapat menghindari terjadinya demineralisasi enamel (11). Derajat keasaman $(\mathrm{pH})$ saliva dalam keadaan normal berada pada rentang 6,8- 7,0 (netral). Kapasitas buffer saliva adalah kemampuan saliva untuk kembali pada $\mathrm{pH}$ normalnya. Saliva memiliki tiga buffer utama yaitu bikarbonat (HCO3-), fosfat (PO4+), dan protein, namun, yang terpenting dari ketiganya adalah bikarbonat (HCO3-) (10).

Saliva adalah cairan kompleks yang diproduksi oleh kelenjar saliva dan mempunyai peranan yang sangat penting dalam mempertahankan keseimbangan ekosistem di dalam rongga mulut. Saliva merupakan hasil sekresi dari beberapa kelenjar saliva, dimana 93\% dari volume total saliva disekresikan oleh kelenjar saliva mayor yang meliputi kelenjar parotid, submandibular, dan sublingual, sedangkan sisa 7\% lainnya disekresikan oleh kelenjar saliva minor yang terdiri dari kelenjar bukal, labial, palatinal, glossopalatinal, dan lingual $(2,3)$ Saliva memegang peranan penting dalam proses karies gigi. Penurunan volume saliva akan memudahkan terjadinya proses karies, karena aliran saliva membantu self cleansing 
permukaan gigi. Saliva mempunyai kapasitas buffer yang dihasilkan fermentasi karbohidrat oleh berbagai macam bakteri rongga mulut. Asam yang terbentuk akan mengalami keseimbangan dengan saliva dan dapat mempengaruhi keasaman saliva, sebagai akibatnya terjadi penurunan $\mathrm{pH}$ saliva (5).

Keasaman ronggat mulut sangat berpengaruh pada proses demineralisasi jaringan keras gigi. Karies merupakan proses hilangnya ion ion mineral secara kronis dan terus menerus dari jaringan gigi seperti email, dentin dan sementum, serta diikuti oleh proses disintegrasi materi organik gigi, yang sebagian besar distimulasi oleh adanya beberapa flora bakteri dan produk-produk yang dihasilkannya (6). Karies gigi disebabkanoleh beberapa faktor antara lain host,substrat, plak yang mengandung bakteri dan waktu. Faktor kepekatan air ludah (viskositas saliva) sebagai bagian dari host berpengaruh terhadap kesehatan rongga mulut karena viskositas saliva yang lebih tinggi akan menurunkan laju aliran (flow rate) saliva yang menyebabkan penumpukkan sisa-sisa makanan yang akhirnya dapat mengakibatkan perkembangan karies. Saliva dengan $\mathrm{pH}$ rendah juga dapat menyebabkan hilangnya ion kalsium, fosfat dan hidroksidari kristal hidroksiapatit. Saliva dengan $\mathrm{pH}$ kritis yaitu 5,5 dapat mengakibatkan disolushidroksiapatit yang disebut demineralisasi pada gigi (7). Saliva berperan penting dalam membantu menjaga kesehatan gigi dan mulut yang berperan dalam fungsi perlindungan. Perannya sebagai pelumas yang melapisi mukosa dan membantu melindungi jaringan mulut terhadap iritasi mekanis, termal dan zat kimia. Fungsi lain termasuk dengan kapasitas dapar dimana bertindak sebagai penyimpanan ion yang memfasilitasi remineralisasi gigi, aktivitas mikroba, yang melibatkan immunoglobulin A,lisozim,laktoferin dan myeloperoxidase. Fungsi perlindungan dilakukan dengan cara meningkatkan sekresi saliva yang dapat diukur melalui $\mathrm{pH}$, laju alir dan viskositasnya (8).

Hasil penelitian Soraya (2013) kopi Robusta memiliki kadar pH asam sekitar 5,54. Menurunnya $\mathrm{pH}$ saliva dan jumlah saliva yang kurang menunjukkan adanya resiko terjadinya karies yang tinggi (9). Hasil penelitian Lubis dan Lindawati (2018) menunjukkan bahwa kopi Robusta menurunkan pH saliva secara signifikan pada konsentrasi 100\%, 50\%, dan $25 \%$. Sedangkan pada konsentrasi 12,5\% tidak signifikan(10). Hal ini terjadi karena $\mathrm{pH}$ ekstrak kopi menunjukkan semakin tinggi konsentrasi ekstrak kopi, $\mathrm{pH}$ kopi juga semakin asam. Diketahui bahwa kopi mengandung karbohidrat sederhana dalam konsentrasi yang tinggi, memfermentasikan karbohidrat akan menghasilkan asam yang dapat menyebabkan penurunan $\mathrm{pH}$ saliva. Perubahan $\mathrm{pH}$ saliva dipengaruhi oleh jenis makanan yang dikonsumsi, stimulasi 
sekresi saliva, laju aliran saliva, waktu, mikroorganisme rongga mulut, dan kapasitas buffer saliva. $\mathrm{pH}$ saliva menjadi turun karena produksi asam dari bakteri setelah konsumsi karbohidrat. Maka kopi dapat digolongkan sebagai minuman yang dapat meningkatkan resiko terjadinya karies gigi apabila dikonsumsi terus menerus dalam waktu lebih dari 30-60 menit (11).

Penelitian Yulisa, Indriani dan Situmorang (2013) tentang kebiasaan minum kopi pada mahasiswa, menunjukkan hasil mayoritas mahasiswa laki laki pengonsumsi kopi bubuk instan siap saji berumur 20 sampai 22 tahun (77,96\%), sedangkan mayoritas responden mahasiswa perempuan pengonsumsi kopi bubuk instan berumur 18 sampai 21 tahun (77,5\%). Berdasarkan tingkat semester, paling banyak adalah mahasiswa semester lima (32,32\%) diikuti semester tujuh (22,22\%), semester tiga (14,14\%), semester satu $(13,13 \%)$, semester Sembilan $(12,12 \%)$, semester sebelas $(5,05 \%)$, serta semester tiga belas $(1,01 \%)(12)$.

\section{METODE PENELITIAN}

Penelitian ini adalah penelitian observasional dengan menggunakan disain cross sectional, yaitu studi epidemiologi yang mempelajari prevalensi, distribusi, maupun hubungan penyakit dan paparan dengan mengamati status paparan, penyakit atau outcome lain secara serentak pada individu- individu dari suatu populasi pada suatu saat. Sampel pada penelitian ini adalah seluruh mahasiswa Program Studi pendidikan Dokter Fakultas Kedokteran Universitas Malikussaleh angkatan 2016-2018 sebanyak 60 orang. Analisis bivariat digunakan terhadap dua variabel yang diduga berhubungan atau berkorelasi yaitu antara variabel bebas dan variabel terikat. Dalam analisis ini meggunakan uji statistik Chi-square untuk melihat perbandingan proporsi pada dua kelompok

\section{HASIL PENELITIAN}

\section{Gambaran Kebiasaan Minum Kopi}

Tabel 1. Gambaran kebiasaan minum kopi pada Mahasiswa Program Studi Kedokteran Universitas Malikussaleh Tahun 2019

\begin{tabular}{lcr}
\hline Kebiasaan Minum Kopi dalam Seminggu & Jumlah & \multicolumn{2}{c}{ Persen } \\
\hline Kurang sama dengan 3 kali & 42 & 70 \\
Lebih dari 3 kali & 18 & 30 \\
Total & 60 & 100 \\
\hline
\end{tabular}


Berdasarkan hasil penelitian, mahasiswa yang mengkonsumsi kopi lebih dari 3 kali dalam seminggu sebanyak 30\% dan yang kurang dari 3 kali seminggu sebanyak 70\%.

\section{Gambaran Derajat pH Saliva}

Tabel 2 Gambaran derajat pH saliva pada Mahasiswa Program Studi Kedokteran Universitas Malikussaleh Tahun 2019

\begin{tabular}{|c|c|c|}
\hline ph Saliva & Jumlah & Persen \\
\hline Asam & 27 & 45 \\
\hline Normal & 33 & 55 \\
\hline Total & 60 & 100 \\
\hline
\end{tabular}

Berdasarkan hasil penelitian, mahasiswa yang mempunyai $\mathrm{pH}$ saliva asam sebanyak $45 \%$ dan $\mathrm{pH}$ normal sebanyak 55\%.

\section{Derajat pH Saliva berdasarkan Kebiasaan Minum Kopi}

Tabel 3 Derajat pH Saliva berdasarkan Kebiasaan Minum Kopi pada Mahasiswa Program Studi Kedokteran Universitas Malikussaleh Tahun 2019

\begin{tabular}{lcccc}
\hline Kebiasaan & \multicolumn{2}{c}{ pH Saliva } & & p value \\
\cline { 2 - 3 } Minum Kopi & Asam & Normal & Total & \\
\hline $\begin{array}{l}\text { Kurang sama } \\
\text { dengan 3 kali }\end{array}$ & $11(26,2 \%)$ & $31(73,8 \%)$ & $42(100,0 \%)$ & \\
Lebih dari 3 kali & $16(88,9 \%)$ & $2(11,1 \%)$ & $18(100 \%)$ & 0,000 \\
Total & 27 & 33 & 60 & \\
& & 33 & 6 & \\
\hline
\end{tabular}

Berdasarkan hasil penelitian, dapat disimpulkan bahwa mahasiswa yang mengkonsumsi kopi kurang sama dengan 3 kali seminggu dan mempunyai pH Saliva yang bersifat asam sebanyak 26,2\%, sedangkan mahasiswa yang mengkonsumsi kopi lebih dari 3 kali seminggu dan mempunyai $\mathrm{pH}$ saliva yang bersifat asam sebanyak 88,9\%. Hasil uji chi-square menunjukkan ada hubungan yang bermakna antara konsumsi kopi dengan derajat pH saliva pada mahasiswa Program Studi Kedokteran Universitas Malikussaleh Tahun 2019.

\section{PEMBAHASAN}

1.Kebiasaan Minum Kopi pada Mahasiswa 
Hasil penelitian menunjukkan bahwa sebanyak 30\% mahasiswa mengkonsumsi kopi lebih dari 3 kali seminggu. Hal ini menunjukkan bahwa minum kopi sudah menjadi gaya hidup bagi mahasiswa. Kebiasaan atau gaya hidup masyarakat yang menginginkan kepraktisan juga dialami oleh generasi muda termasuk mahasiswa, yang merupakan konsumen dan penggemar produk-produk instan siap saji termasuk kopi. Kopi menjadi pilihan yang diambil oleh mahasiswa untuk menemani saat belajar malam terutama jikasedang banyak tugas perkuliahan yang harus segera dikumpulkan. Kopi mengandung kafein yang dapat mempercepat kerja otot jantung dan memperlebar pembuluh darah karena merupakan stimulan saraf pusat. Dengan begitu asupan oksigen dan glukosa ke otak dapat terus mengalir sehingga membuat otak terus bekerja. Stimulasi sistem saraf pusat yang meningkat akan meningkatkan kewaspadaan, kecepatan dalam berpikir, fokus dan koordinasi tubuh yang baik (16).

Pada tahap pengenalan kebutuhan, manfaat utama yang dicari mahasiswa dari pembelian kopi bubuk instan siap saji adalah penghilang rasa kantuk $(43,86 \%)$. Motivasi yang melandasi konsumen membeli kopi bubuk instan siap saji adalah perwujudan dari gaya hidup $(51,52 \%)$ dan yang menjadi halangan mahasiswa untuk membeli kopi bubuk instan siap saji adalah promosi tidak menarik dan harganya yang mahal (23,23\%). Mahasiswa mendapatkan informasi tentang kopi bubuk instan siap saji dari media elektronik baik televisi, internet maupun radio $(67,74 \%)$. Iklan-iklan kopi bubuk instan siap saji yang ditayangkan baik di televisi, internet maupun disiarkan di radio menjadi sumber informasi mahasiswa dari media elektronik. Melalui media televisi inilah produk kopi instan siap saji lebih dikenal dan dikonsumsi oleh masyarakat, mengingat penayangan iklan kopi instan siap saji dengan frekuensi penayangan yang sering. Sehingga akan mempengaruhi minat mahasiswa untuk membeli kopi instan siap saji tersebut (15).

\section{2. pH Saliva pada Mahasiswa}

Hasil penelitian menunjukkan 45\% pH saliva mahasiswa bersifat asma. Saliva adalah air dan biasanya berbusa yang diproduksi mulut manusia dan beberapa hewan. Saliva disekresikan oleh kelenjar saliva. Saliva manusia mengandung air paling banyak, tetapi juga mengandung elektrolit, mukus, komponen anti bakteri dan berbagai enzim sebagai bagian dari proses pencernaan makanan awal, enzim-enzim dalam saliva menghancurkan beberapa produk lemak sampai level molekuler. Saliva membantu pencernaan mekanis yang dilakukan 
oleh gigi, melindungi gigi dari bakteri yang dapat menyebabkan karies. Selain itu saliva berfungsi sebagai pelumas dan pelindung gigi, lidah, dan jaringan lunak dalam mulut. $\mathrm{pH}$ saliva merupakan derajat keasaman yang terkandung dalam saliva atau air ludah yang berkisar dari 0 - 14 dengan perbandingan terbalik, dimana semakin rendah nilai $\mathrm{pH}$, maka semakin asam kandungan didalam saliva. Sebaliknya, meningkatnya nilai $\mathrm{pH}$ berarti bertambahnya basa dalam saliva. Semakin rendah pH saliva maka karies cenderung semakin tinggi (17).

Derajat keasaman $(\mathrm{pH})$ saliva berkisar antara 6,2-7,6 dengan rata-rata 6,7. Aksi mikroorganisme yang menfermentasi berbagai jenis karbohidrat menjadi asam, mengakibatkan penurunan pH saliva. Penurunan yang mencapai pH kritis akan menyebabkan terjadinya proses demineralisasi jaringan keras gigi. Saliva berperan penting dalam penghambatan proses karies dengan adanya komponen-komponen yang mempunyai daya anti bakteri dan fungsi mekanis yang dimilikinya. Saliva berperan penting dalam membantu menjaga kesehatan gigi dan mulut yang berperan dalam fungsi perlindungan. Perannya sebagai pelumas yang melapisi mukosa dan membantu melindungi jaringan mulut terhadap iritasi mekanis, termal dan zat kimia. Fungsi lain termasuk dengan kapasitas dapar dimana bertindak sebagai penyimpanan ion yang memfasilitasi remineralisasi gigi, aktivitas mikroba, yang melibatkan immunoglobulin A,lisozim,laktoferin dan myeloperoxidase. Fungsi perlindungan dilakukan dengan cara meningkatkan sekresi saliva yang dapat diukur melalui $\mathrm{pH}$, laju alir dan viskositasnya (8).

\section{Derajat pH Saliva pada Mahasiswa yang Mengkonsumsi Kopi}

Penelitian yang dilakukan pada tahun 2016 menunjukkan bahwa adanya pengaruh yang signifikan antara konsumsi kopi dengan penurunan $\mathrm{pH}$ saliva karena kopi mengandung zat yang bersifat asam seperti asam klorogenat dan asam nikotinat serta adanya kandungan karbohidrat sederhana dalam konsentrasi yang tinggi seperti monosakarida dan sukrosa. Pada penelitian yang dilakukan Tecky Indriana pada tahun 2011, salah satu tujuan dilakukan penilaian risiko karies ialah untuk membantu mengidentifikasi faktor yang berperan pada karies tersebut sehingga membantu memprediksi kerentanan seseorang terhadap karies saat ini atau karies yang akan datang. Salah satu pemeriksaan dalam penilaian risiko karies yaitu pemeriksaan aliran dan kekentalan saliva. Kecepatan aliran saliva yang rendah dan kekentalan saliva yang tinggi dapat menunjukkan tingginya proses terjadinya gigi karies. 
Sebaliknya dalam kecepatan aliran yang tinggi dan kekentalan saliva yang rendah menunjukkan rendahnya kejadian karies (16).

Saliva merupakan cairan eksokrin yang terdiri dari berbagai komponen yang kompleks, tidak berwarna, serta berperan dalam proses pencernaan makanan, pengaturan keseimbangan air, menjaga integritas gigi, aktivitas antibakterial, buffer, dan berperan penting bagi kebersihan rongga mulut (11). Stimulus kimiawi yang bersifat asam merupakan stimulus yang paling kuat dalam meningkatkan sekresi saliva, dimana dapat berubah dengan adanya aktivitas refleks yang melibatkan sistem saraf pusat (17).

Diketahui bahwa kopi mengandung karbohidrat sederhana dalam konsentrasi yang tinggi, memfermentasikan karbohidrat akan menghasilkan asam yang dapat menyebabkan penurunan $\mathrm{pH}$ saliva. Perubahan $\mathrm{pH}$ saliva dipengaruhi oleh jenis makanan yang dikonsumsi, stimulasi sekresi saliva, laju aliran saliva, waktu, mikroorganisme rongga mulut, dan kapasitas buffer saliva. pH saliva menjadi turun karena produksi asam dari bakteri setelah konsumsi karbohidrat. Maka kopi dapat digolongkan sebagai minuman yang dapat meningkatkan resiko terjadinya karies gigi apabila dikonsumsi terus menerus dalam waktu lebih dari 30-60 menit (4). Derajat keasaman $(\mathrm{pH})$ dan kapasitas buffer saliva dipengaruhi oleh perubahan-perubahan yang disebabkan oleh irama cyrcadian, diet dan rangsangan terhadap perangsangan kecepatan sekresi saliva. Konsumsi kopi secara signifikan mengurangi produksi saliva. Efek kafein kira-kira 6,5\% rangsangan (15). Hasil penelitian ini yang dilakukan oleh Rosdiana pada tahun 2013 tentang pengaruh kopi arabika (coffee arabica) dan kopi robusta (coffee canephora) terhadap viskositas saliva secara in vitro. Ratarata viskositas lebih tinggi pada kelompok pecandu kopi, hal ini menunjukan bahwa saliva tersebut menjadi lebih kental. Viskositas yang tinggi (saliva kental) dapat menyebabkan laju aliran saliva rendah sehingga dapat menyebabkan penumpukan sisa-sisa makanan yang pada akhirnya dapat menyebabkan karies, sedangkan viskositas yang rendah (saliva encer) akan meningkatkan laju aliran saliva, sehingga didapatkan efek self cleansing yang baik yang dapat mengurangi terjadinya karies gigi sehingga dapat disimpulkan bahwa viskositas saliva meningkat pada pecandu kopi dibandingkan pada kelompok bukan pecandu kopi (17).

\section{KESIMPULAN}

1. Mahasiswa yang mengkonsumsi kopi lebih dari 3 kali dalam seminggu sebanyak $30 \%$ dan yang kurang dari 3 kali seminggu sebanyak $70 \%$. 
2. Mahasiswa yang mempunyai $\mathrm{pH}$ saliva asam sebanyak $45 \%$ dan $\mathrm{pH}$ normal sebanyak $55 \%$.

3. Ada hubungan yang bermakna antara konsumsi kopi dengan derajat $\mathrm{pH}$ saliva pada mahasiswa Program Studi Kedokteran Universitas Malikussaleh.

\section{REFERENSI}

1. Yulisna, R. 2016. Pengaruh Penambahan Bubuk Cassiavera pada Bubuk Kopi Robusta dengan Dua Cara Penyeduhan terhadap Karakteristik Mutu Bubuk Kopi Campuran dan Minuman Kopi. Thesis. Universitas Andalas. Padang. Hal: 1.

2. Andriany, P., Hakim, R. F., \& Mahlianur. 2012. Pengaruh Konsumsi Kopi Ulee Kareng (arabika) Terhadap pH Saliva Pada Usia Dewasa Muda. Dentika Dental Journal. Vol.17. No. 2. Hal: 151

3. Mariko, Z. F. 2014. "Pengaruh Konsumsi Kopi Terhadap Skor Plak pada Mahasiswa Fakultas Teknik Universitas Syiah Kuala". Skripsi. Universitas Syiah Kuala. Banda Aceh.

4. Imran, H., Nurdin, \& Nasri. 2016. Pengaruh Konsumsi Kopi Terhadap Penurunan pH Saliva pada Usia Penurunan $\mathrm{pH}$ Saliva pada Usia Dewasa. Jurnal Penelitian Suara Forikes. Vol. 8. No. 3. Hal: 161.

5. Probosari, N 2004, "Peranan Pengunyahan Makanan Terhadap Perbedaan Perubahan Volume, pH dan Viskositas Saliva pada Anak Kelompok Karies dan Anak Non Karies". Thesis. Universitas Airlangga. Surabaya

6. Pratama, S. 2008. "Pengaruh Pengunyahan Permen Karet Yang Mengandung Xylitol Terhadap Laju Aliran Saliva Pada Anak Usia 10-12 Tahun Di Pesantren AlHamidiyah Depok Tahun 2008". Skripsi.Fakultas Kedokteran Gigi Universitas Indonesia. Jakarta. Hal: 4.

7. Sulendra, K. T., Fatmawati, D. W., \& Nugroho, R. 2013. Hubungan pH dan Viskositas Saliva terhadap Indeks DMF-T pada Siswa-siswi Sekolah Dasar Baletbaru I dan Baletbaru II Sukowono Jember. Artikel Ilmiah Hasil Penelitian Mahasiswa 2013. Universitas Jember.

8. Rodian, M., Satari, M. H., \& Rolleta, E2011. Efek Mengunyah Permen Karet yang Mengandung Sukrosa, Xylitol, Probiotik Terhadap Karakteristik Saliva. Dentika Dental Journal. Vol. 16. No. 1. Hal: 44-48.

9. Soraya c, sunnati, Munawar S. Pengaruh kopi robusta dan kopi arabika terhadap perubahan $\mathrm{pH}$ saliva (in vitro). Cakra dent J 2013; 5(1): 475-541.

10. Lubis,MRF.,Lindawati,Y . Efek ekstrak biji kopi robusta (coffeacanephora) terhadap ph saliva dan pertumbuhan bakteri staphylococcus aureus 309 (atcc 29213 ${ }^{\mathrm{TM}}$ ) (in vitro). 
Jurnal Ilmiah PANNMED (2018) diunduh dari ojs.poltekkes-medan.ac.id

11. Lutfi Yulisa, Yaktiworo Indriani, Suriaty Situmorang. Perilaku Konsumsi Mahasiswa Universitas Lampung Terhadap Kopi Bubuk Instan Siap Saji. JIIA, Volume 1, No. 4, Oktober 2013.

12. Amerongen A Van Nievw. ludah dan kelenjar ludah. Yogyakarta : Gajah Mada University press.1-3,6-7,15-16, 2009

13. Mariko, Z. F. 2014. "Pengaruh Konsumsi Kopi Terhadap Skor Plak pada Mahasiswa Fakultas Teknik Universitas Syiah Kuala". Skripsi. Universitas Syiah Kuala. Banda Aceh

14. Probosari, N 2004, "Peranan Pengunyahan Makanan Terhadap Perbedaan Perubahan Volume, pH dan Viskositas Saliva pada Anak Kelompok Karies dan Anak Non Karies". Thesis. Universitas Airlangga. Surabaya

15. Ginting, Rosdiana. 2013. "Pengaruh Kopi Arabika (Coffee arabica) dan Kopi Robusta (Coffee cannephora) Terhadap Viskositas Saliva Secara In Vitro". Skripsi. Fakultas Kedokteran Gigi Universitas Syiah Kuala. Banda Aceh.

16. Indriana T. 2011. Perbedaan Laju Aliran Saliva dan pH Karena Pengaruh Stimulus Kimiawi dan Mekanik. J Kedokteran Meditek. Vol. 17. No. 44

17. Berkovitz BK, Moxham BJ, Linden RW, Sloan AJ. Oral Biology. Churchill Livingstone Elsevier; China 2011: 82-3. 